\title{
The Relevance of a Multilateral Services Trade Agreement for the World Economy
}

\author{
by Sir Brian Corby*
}

\section{Introduction}

In this keynote address I intend to stress the relevance of a multilateral services trade agreement for the world economy.

In many respects, this month of May 1991 is the ideal moment to be holding such a conference. The US Congress has the fate of the GATT Uruguay Round of trade negotiations in its hands as it decides whether or not to grant an extension of the US "fast-track" negotiating authority. The Congress will no doubt make its decision conscious of the need to ensure that both the US and its trading partners need a quality agreement and material liberalisation in many diverse areas of trade and services. Any failure to give the US "fasttrack" extension will kill the Uruguay Round and would lead to increased business uncertainty and the possibility of damaging tit-for-tat retaliation and restrictionist or protectionist actions. The US is, of course, better equipped through having its section 301 to take bilateral or rather unilateral actions. But the solving of world trade problems needs something rather better, ideally on a multilateral basis.

We need to keep the Uruguay Round alive because it could lead to better understanding and trust between nations and give us for the first time an agreement to cover services (a General Agreement on Trade in Services - GATS). We are concerned here today with global services and trade liberalisation, both of which should play an increasingly significant part in creating greater confidence in the world trading system in general, and in GATT in particular, alongside the many other important GATT subjects under negotiation in the Uruguay Round.

Before the launch of the Uruguay Round of GATT negotiations in September 1986, the CBI was already advocating:

- increased credibility for GATT: the outlawing of unilateral action and strengthened arrangements for dispute settlement;

- extended coverage of GATT rules and their application to services, agricultural trade, textiles, intellectual property and trade distorting investment policies;

* President of the Confederation of British Industry, Chairman of the Prudential Corporation p.l.c., London, President of the Geneva Association. Keynote address given at the Second Geneva International Forum on Global Services and Trade Liberalisation on May 21, 1991. 
- improved conditions for market access by balanced reduction of tariffs and non-tariff barriers;

- the acceptance by all contracting parties, whatever their level of development, of an appropriate share of the obligations as well as the benefits of GATT membership;

- improvements and updating of provisions allowing commercial defence to provide effective and workable safeguards, anti-dumping and anti-export subsidy rules.

These CBI objectives have, throughout the Round, been shared by Community industry in UNICE, and by HMG and the European Community.

\section{Trends in the world economy}

Looking at the world economy as a whole, growth has for some time been slowing down in most countries' economies, and has ceased in some. Interest rates have been high to reduce earlier overheating and inflationary pressures. Higher oil prices and the uncertainties induced by the Gulf Crisis have left a severe mark in many services sectors, particularly tourism, air transport and shipping services.

Although inflation is mainly under control again, a non-inflationary boost to growth is sorely needed from international trade. Trade liberalisation can help to reduce unemployment, a tangible benefit in the shorter term, and in the longer term can provide gains from expanded business opportunities. For these reasons, we cannot afford to delay the completion of the Uruguay Round which we would wish to see successfully concluded this year before the US Presidential elections in 1992 produce distractions. The idea that the Round should run on for a further 2 years until 1993 is not something that we would favour.

There is in the world economy a tendency for the formation of larger regional trading blocs. In Europe it is led by the expanding EC and its closer links with EFTA, and soon with other European countries to the east. In North America the US/Canada Free Trade Agreement may be expanded into a trilateral deal with Mexico. In Latin America there are moves for a free trade zone in the southern cone. In South East Asia and the Pacific Rim there are similar explorations afoot. Australia and New Zealand have already gone a long way in a thorough-going pact on liberalisation.

Such blocs are predicated on freer trade. Provided they do not look in on themselves and cause trade diversion or create a much talked about "Fortress Europe" or "Fortress North America" they may be not only perfectly GATT-worthy but in fact they may promote globally even greater volumes of trade and investment.

\section{Services in the world economy}

I now turn to services in the world economy and to the enormous growth in world trade in services.

In many countries services account for the largest share of employment, over $60 \%$ in the UK, $68 \%$ in the US and $75 \%$ in Australia, for example. Most job creation for the past two decades in the advanced economies has been in services.

As President Bush succinctly put it in his recent submission to Congress "Services trade... accounts for nearly $\$ 90$ billion in US exports, 60 percent of US output and 90 percent of the new jobs created in the US since 1980". In the UK, private invisible exports grossed over ₹ 104,000 million in 1989 , accounting for over half the country's foreign 
earnings and representing $141 / 2 \%$ of world invisible trade. They produced a surplus of over f 11,200 million in 1989 and provided growing employment opportunities. In fact, the UK has produced an annual surplus in trade in services for almost 200 years.

Technology has enabled new services to be created and traded across borders. Other sectors are incorporating an increasing proportion of services during their production, marketing and distribution processes. There is of course a close relationship between goods and services production. Three quarters or more of added value in many sectors arises through service activity.

Some $40 \%$ of the world stock of Foreign Direct Investment (FDI) is for the provision of services, and over half the flow is mainly in the distribution and financial services sectors, and closely related to the selling and maintenance of goods.

Services also play a key part in developing world markets, and in the globalisation of the world economy. In all economies, services reach into every corner, and have a major impact of efficiency through improved productivity and quality.

They also play a key part in economic and social development in the newly developing countries which are often competing to attract investment to secure enhanced prosperity. It is, in fact, only in this way that such countries may be able to reduce their burden of debt and, as greater numbers of people leave the land, help to keep down unemployment. Services can also play a crucial role in the primary industries of such countries by bringing technological changes to their manufacturing sectors.

By protecting service industries and sectors, considerable costs are placed on the shoulders of both consumers and governments. Arguments to protect, justified on the grounds or nurturing infant industries or guaranteeing national security or reinforcing national sovereignty or culture, are legion. A proper appreciation of what stands to be gained by integration into a liberal world system must however be more widely instilled and appreciated.

\section{Services in World Trade}

Turning now to the role of services in world trade; although there has been a slow down in the rate of growth of world trade since the peak of 1988, expansion has continued at a faster rate than world output. In 1990 the volume of traded goods rose by $5 \%$, down from $7 \%$ in 1989 . But services trade grew at $12 \%$ to a total of over $\$ 770$ billion. This represents about $25 \%$ of world trade. These figures must however be used with care, since they are subject to a wide margin of error.

The fastest growth in services has been in the financial and business or intermediate services such as banking, insurance, advertising, computing, consultancy, legal and accounting - all underpinning the production of both goods and other services. Commercial services as a whole account for half the recorded world trade. They also equal the sum of world exports of food and fuels. Or to put it another way, the total of all trade in cars and electronic products.

It is quite clear therefore that the provision of better and cheaper services stimulates merchandise trade. This is particularly so in key sectors such as transport and telecommunications. 


\section{Services and the role of GATT}

I now turn to services and the role of GATT. For the first time ever services are being negotiated within a GATT Round - the current Uruguay Round, the most ambitious yet attempted. All that I have been saying underlines the need to extend the rule of multilateral agreements to other forms of trade than the traditional GATT one of manufactures. These other areas must include services, but incidentally also, as I have said, agriculture, the defence of intellectual property, the reintegration of textiles into the GATT rules and, where appropriate, to investment rules as well. Since the Round is so ambitious and the prizes for success so significant, the risks of failure of the Uruguay Round are considerable. It will be a great pity if we do not secure a successful outcome, since this will mean that key sectors of world trade will remain outside the important disciplines of the GATT.

A pointer to the importance of the GATT is the number of non-market economies now showing interest in more liberal trading systems: China has applied to rejoin the GATT and the USSR is also taking a keen interest as an observer, with a view perhaps to eventual membership.

Significantly, on services we should be starting now to build with the long term future in mind. We must ensure that the right foundations are laid. There are many highly complex issues we must grapple with.

Governments have set themselves incredibly ambitious goals in the GATT Round. Perhaps it is no wonder that success will not come easily. Markets are developing at an ever increasing speed whilst attitudes and laws tend to lag far behind. This gives rise to problems. But a problem is an opportunity and, though regulators tend to be conservative and need to take into account many considerations such as consumer and environmental protection, the soundness of monetary systems, culture and sovereignty issues, their understandable nervousness must be put aside as they take up the challenge.

All economies can bring a distinctive contribution and play their part by upholding the quality and integrity of the system. Most want to participate in the global free market. Since services are often being produced by networks, any agreement on services must recognise the distinctive way in which each contributes to the overall network. We need a structure that is enhanced by the inclusion of more services rather than destabilised by it.

The Uruguay Round is one endeavour, with the major issues closcly interlinked, with each country placing different emphasis on the various cross-linkages. We cannot look at services and hope for a deal in isolation from agriculture - but then too, in the real world these matters are not separate either. Half measures will not really give us the agreement on scrvices that we are seeking. As the Director General of GATT has said, its "members" economic interests are best served through a trading system which is based upon open markets and fair competition secured through agreed multilateral rules and disciplines". At GATT this calls for a sensitive balance between rights and obligations.

What is needed is a good Services Agrecment with strong libcralising dynamic and which can be our contribution in this area of life to the New World Order to which the Americans aspirc. Officials need to rcly on a full input from the private sector to ensure that they are fully appraised of the professional needs and problems, which only those directly involved in the services concerned can know. 
One alternative sometimes talked about to a proper multilateral agreement is a series of bilateral deals. But these could only make our markets less predictable and more costly to serve. Experience tends to indicate that such bilateralism leads to unfortunate and damaging trade disputes. It should be easier for governments to accept multilaterally agreed market opening, than to respond to bilateral confrontation and all the attendant problems. For 40 years GATT has presided over the greatest ever expansion in world trade in manufactures and we need to extend this to those other key sectors which have such a significant role to play in the future. The GATT now contains over 100 contracting parties, each of whom subscribes to the multilateral principles embodied in the General Agreement. It mobilises the support of nations desirous of expanding trade in the best possible way and, through participation, underpins the best method of delivering goods and services through comparative advantage under appropriate rules and disciplines. Let us make sure that trade in services now has the opportunity of benefiting from such a regime. 